\title{
Assessment of the possibility of zearalenone removal by soil bacteria of the genus Rhodococcus
}

\section{Ocena możliwości usuwania zearalenonu przez bakterie glebowe z rodzaju Rhodococcus}

\author{
Romuald Gwiazdowski ${ }^{1 *}$, Daniela Gwiazdowska ${ }^{2}$, Krzysztof Juś ${ }^{2}$, Agnieszka Waśkiewicz ${ }^{3}$
}

\section{Summary}

The aim of the study was to assess the possibility of reducing the content of zearalenone by soil bacteria of the genus Rhodococcus in model conditions. The experiment was carried out for 72 hours in a pepton broth as well as in a buffer, controlling the amount of toxin every 24 hours. The results showed that the tested strains of Rhodococcus bacteria were able to reduce of zearalenone content in relation to the control samples. The degree of reduction of zearalenone content was dependent on the bacteria strain as well as time incubation and environment, in which the process was conducted. In the samples collected during the incubation derivatives were not observed.

Key words: mycotoxins; zearalenone; Rhodococcus

\section{Streszczenie}

Celem pracy była ocena możliwości redukcji zawartości zearalenonu przez bakterie glebowe rodzaju Rhodococcus w warunkach modelowych. Proces prowadzono przez 72 godziny w pożywce peptonowej oraz w buforze, kontrolując ilość toksyny co 24 godziny. Otrzymane wyniki wykazały, że badane szczepy bakterii powodują redukcję ilości zearalenonu w stosunku do prób kontrolnych. Stopień redukcji stężenia zearalenonu był uzależniony od szczepu bakterii, czasu inkubacji oraz od środowiska, w jakim prowadzono proces. W próbkach zebranych w trakcie inkubacji nie obserwowano wystąpienia związków pochodnych.

Słowa kluczowe: mikotoksyny; zearalenon; Rhodococcus

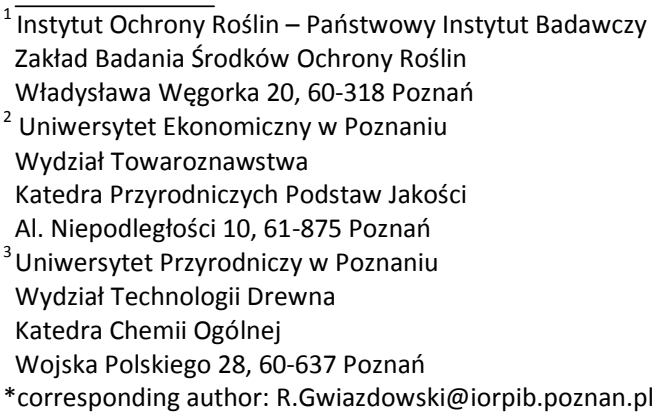




\section{Wstęp / Introduction}

Obecność patogennych grzybów i wytwarzanych przez nie mikotoksyn w płodach rolnych każdego roku przyczynia się do obniżenia plonów i pogorszenia ich jakości. Mikotoksyny, czyli wtórne metabolity wytwarzane przez grzyby strzępkowe, wykazują dużą toksyczność względem ludzi i zwierząt (Bennet i Klich 2003). Do dziś poznano i opisano około 400 tych metabolitów, należy jednak przypuszczać, że lista tych związków nie jest zamknięta. Do mikotoksyn o szczególnym znaczeniu ekonomicznym zaliczane są: aflatoksyny, ochratoksyna A oraz toksyny fuzaryjne. Do najważniejszych mikotoksyn fuzaryjnych należą: trichoteceny grupy A i B, zearalenon i fumonizyny (Suchorzyńska i Misiewicz 2009). Niebezpieczeństwo związane $\mathrm{z}$ występowaniem mikotoksyn w płodach rolnych wiąże się z możliwością przedostawania się tych związków do łańcucha żywności i pasz, stanowiąc tym samym zagrożenie dla ludzi i zwierząt. Oddziaływanie mikotoksyn na organizm żywy jest bardzo zróżnicowane, ponieważ poszczególne toksyny charakteryzują się właściwościami: kancerogennymi, teratogennymi, estrogennymi, embriotoksycznymi czy mutagennymi (Chełkowski 2009). Powszechność występowania toksynotwórczych grzybów, jak również negatywne oddziaływanie mikotoksyn na organizm sprawia, że ich zawartość w produktach żywnościowych i paszach jest ważnym wskaźnikiem ich jakości i bezpieczeństwa (Pokrzywa i wsp. 2007). Tymczasem z danych FAO (Food and Agriculture Organization) z 2001 roku wynika, że na świecie około $25 \%$ plonów, żywności oraz pasz jest zanieczyszczona przez mikotoksyny. Komisja Codex Alimentarus w 2003 roku wydała $\mathrm{z}$ kolei opinię wskazującą, że uniknięcie spożycia jakiejkolwiek ilości mikotoksyn jest praktycznie niemożliwe (Kapturowska i wsp. 2010), co jest związane przede wszystkim z dużą opornością tych substancji na czynniki: fizyczne, chemiczne i biologiczne (Emrich i wsp. 2008).

Pomimo stosowania różnych sposobów zapobiegania rozwojowi toksynotwórczych grzybów, jak fungicydy czy zabiegi agrotechniczne, problem obecności mikotoksyn jest wciąż aktualny. Z doświadczeń przeprowadzonych przez Twarużek i wsp. (2012) wynika, że w ziarnach kukurydzy zebranych w całej Polsce w latach 2009-2011 obecne są toksyny fuzaryjne, takie jak: zearalenon, fumonizyny, niwalenol, deoksyniwalenol, toksyna T-2 i HT-2. Ich obecność stwierdzono niemal we wszystkich, badanych próbach. Wobec tego istnieje duża potrzeba poszukiwania nowych i skutecznych sposobów na ograniczenie ilości mikotoksyn w żywności i paszach. Jedną $\mathrm{z}$ możliwości jest zastosowanie metod mikrobiologicznych.

Zearalenon jest jedną z powszechniej występujących w przyrodzie mikotoksyn. Pod względem chemicznym jest to $\beta$-rezorcyno-lakton, zawierający $w$ swojej strukturze pierścień rezorcynowy oraz makrocykliczny pierścień laktonowy, którego budowa przypomina układ hormonów sterydowych. Z tego powodu toksynę tę określa się jako niesteroidowy mikoestrogen (Bennet i Klich 2003). Obecność zearalenonu odnotowuje się w licznych gatunkach zbóż, takich jak: owies, żyto, pszenica, ryż czy kukurydza, w paszach przeznaczonych dla zwierząt, jak również w kiszonkach.

Wykorzystanie mikroorganizmów w celu dekontaminacji mikotoksyn obecnych $\mathrm{w}$ środowisku lub żywności jest zgodne $\mathrm{z}$ obserwowaną obecnie tendencją do wprowadzania przyjaznych środowisku metod usuwania tych metabolitów. Duże zainteresowanie budzą mikroorganizmy pochodzące ze środowiska naturalnego, m.in. z gleby, które wykazują właściwości antagonistyczne w stosunku do patogenicznych grzybów. Przykładem tego typu mikroorganizmów są bakterie z rodzaju Rhodococcus. Są to gramdodatnie, tlenowe, niezarodnikujące bakterie powszechnie występujące w glebie (Alberts i wsp. 2006). Niektóre szczepy tych bakterii są zdolne do wytwarzania białkowych substancji, takich jak rhodopeptyna, charakteryzujących się właściwościami fungistatycznymi, między innymi wobec grzybów rodzaju Fusarium (Chiba i wsp. 1999). Bakterie Rhodococcus są zdolne do rozkładu różnego rodzaju związków, takich jak: izopropylobenzen, dichloroetan, pestycydy, leki, składniki zanieczyszczeń przemysłowych (Łobocka 2002) oraz polichlorobifenyle, które są zaliczane do jednych z najbardziej toksycznych zanieczyszczeń środowiskowych (Masai i wsp. 1997). Zdolność do degradacji tych związków decyduje o ważnej roli jaką pełnią bakterie $\mathrm{z}$ rodzaju Rhodococcus w usuwaniu toksycznych zanieczyszczeń ze środowiska (Dua i wsp. 2002). Właściwości fungistatyczne i szerokie spektrum dekontaminacji różnego rodzaju toksycznych związków, wskazują na potencjalną zdolność tych bakterii do rozkładu mikotoksyn oraz ograniczania ich ilości w środowisku.

Celem pracy było określenie potencjalnej zdolności bakterii Rhodococcus erythropolis i $R$. fascians do redukcji zawartości zearalenonu w warunkach modelowych.

\section{Materiały i metody / Materials and methods}

\section{Material badawczy}

W badaniach zastosowano dwa szczepy bakterii: Rhodococcus erythropolis PCM 2150 oraz R. fascians PCM 2291, pochodzące z kolekcji Instytutu Immunologii i Terapii Doświadczalnej we Wrocławiu. Bakterie hodowano na płynnej pożywce peptonowej (pepton - $10 \mathrm{~g}$, enzymatyczny hydrolizat kazeiny $-2 \mathrm{~g}$, ekstrakt drożdżowy $-2 \mathrm{~g}$, chlorek sodu $-6 \mathrm{~g}$, glukoza $-20 \mathrm{~g}$, agar $-20 \mathrm{~g}$, woda destylowana $1000 \mathrm{~cm}^{3}$ ), $\mathrm{pH} 7,0$, w temperaturze $30^{\circ} \mathrm{C}$ przez 48 godzin. Zearalenon (ZEA), wykorzystany w doświadczeniach został zakupiony w firmie Sigma-Aldrich.

\section{Ocena redukcji ZEA przez bakterie}

Z płynnych hodowli $R$. erythropolis PCM 2150 i $R$. fascians PCM 2291 oddzielono komórki bakteryjne od pożywki przez wirowanie w jałowych probówkach wirówkowych (7000 rpm/min, 10 minut). Następnie pożywkę zlano znad osadu, po czym komórki zawieszono w jałowym buforze PBS (Phosphate Buffered Saline), pH 7,0. Całość wymieszano, otrzymując zawiesinę bakterii 
w buforze o gęstości $10^{7} \mathrm{jtk} / \mathrm{cm}^{3}$, a następnie rozdzielono po $1 \mathrm{~cm}^{3}$ do wyjałowionych probówek typu eppendorf (pojemność $1,5 \mathrm{~cm}^{3}$ ) i ponownie odwirowano zawiesiny (10 $000 \mathrm{rpm} / \mathrm{min}, 5 \mathrm{minut}$ ). Po odwirowaniu bufor zlano znad osadu, a do komórek bakterii dodano po $1 \mathrm{~cm}^{3}$ przygotowanego wcześniej roztworu ZEA w buforze PBS lub pożywce peptonowej o stężeniu $5 \mu \mathrm{g} / \mathrm{cm}^{3}$ i całość dokładnie rozmieszano. Tak przygotowane próbki inkubowano w temperaturze pokojowej (ok. $20^{\circ} \mathrm{C}$ ) przez 72 godziny. Próby kontrolne stanowiły roztwory ZEA bez dodatku komórek bakterii. Próby do analizy HPLC (Highperformance liquid chromatography) pobierano w różnych odstępach czasowych ( $0 \mathrm{~h}, 24 \mathrm{~h}, 48 \mathrm{~h}, 72 \mathrm{~h})$ i oznaczano w nich stężenie zearalenonu metodą HPLC. Próbki do analizy wirowano $(14000 \times \mathrm{g}, 5$ minut $)$, a supernatant filtrowano przez filtry Millex GS $0,22 \mu \mathrm{m}$ (Millipore Bedford MA, USA). Wyniki podano w $\mu \mathrm{g} / \mathrm{cm}^{3}$. Wszystkie badania wykonano $\mathrm{w}$ trzech powtórzeniach.

\section{Oznaczanie zawartości zearalenonu metodą HPLC}

Zearalenon oznaczano metodą wysokociśnieniowej chromatografii cieczowej (HPLC) z zastosowaniem aparatu Waters 2695 (Waters Company, Milford, MA, USA), $\mathrm{z}$ zestawem detektorów Multi Fluorescence Detector Waters 2475, Photodiode Array Detector Waters 2996 oraz kolumną $C_{18}$ Nova Pack 3,9 × $150 \mathrm{~mm}$. Parametry rozdziału były następujące: faza ruchoma: acetonitryl:woda:metanol (46:46:8, v/v/v); przepływ: $0,5 \mathrm{~cm}^{3} / \mathrm{min}$; objętość dozowania: $10-20 \mu \mathrm{l}$; czas retencji: $8,45 \mathrm{~min}$; próg wykrywalności: $0,3 \mathrm{ng} / \mathrm{g}$. Ze względu na możliwość przekształcenia zearalenonu w związki pochod- ne, w próbkach oznaczano również zawartość $\alpha$ - i $\beta$-zearalenolu.

\section{Analiza statystyczna}

Istotność różnic pomiędzy wartościami średnimi określano za pomocą testu t-Studenta z wykorzystaniem programu STATISTICA v. 10.

\section{Wyniki i dyskusja / Results and discussion}

Bakterie z rodzaju Rhodococcus należą do mikroorganizmów o dużym potencjale biodegradacyjnym, jednak dane literaturowe dotyczące możliwości degradacji bądź transformacji mikotoksyn są nieliczne. W prezentowanej pracy podjęto próbę wykorzystania dwóch szczepów bakterii z rodzaju Rhodococcus, (R. erythropolis PCM 2150 i $R$. fascians PCM 2291), do redukcji zawartości zearalenonu w warunkach modelowych. W badaniach zastosowano dwa roztwory modelowe, bufor PBS i pożywkę peptonową. Rezultaty doświadczenia przedstawiono w tabeli 1.

Na podstawie uzyskanych wyników można stwierdzić, że obydwa badane szczepy bakterii z rodzaju Rhodococcus powodowały redukcję zawartości zearalenonu, niezależnie od środowiska, w jakim prowadzono proces. Należy podkreślić, że stopień redukcji ilości toksyny różnił się w zależności od badanego szczepu, jak i roztworu modelowego. W próbkach nie odnotowano obecności produktów metabolizmu zeralenonu, co może sugerować, że mechanizmem odpowiadającym za obniżenie zawartości toksyny była adsorpcja do powierzchni komórek.

Tabela 1. Redukcja zawartości zearalenonu przez bakterie $R$. erythropolis PCM 2150 oraz R. fascians PCM 2291

Table 1. The reduction of zearalenone content by $R$. erythropolis PCM 2150 and $R$. fascians PCM 2291

\begin{tabular}{|c|c|c|c|c|c|}
\hline \multirow[b]{2}{*}{$\begin{array}{c}\text { Czas } \\
\text { inkubacji } \\
\text { Time } \\
\text { of incubation } \\
{[\mathrm{h}]}\end{array}$} & \multirow[b]{2}{*}{$\begin{array}{l}\text { Kontrola } \\
\text { Control } \\
{\left[\mu \mathrm{g} / \mathrm{cm}^{3}\right]}\end{array}$} & \multicolumn{2}{|c|}{ Rhodococcus erythropolis РCM 2150} & \multicolumn{2}{|c|}{ Rhodococcus fascians PCM 2291} \\
\hline & & $\begin{array}{c}\text { zawartość ZEA } \\
\text { w próbach po inkubacji } \\
\text { the content of ZEA in } \\
\text { samples after incubation } \\
{\left[\mu \mathrm{g} / \mathrm{cm}^{3}\right]}\end{array}$ & $\begin{array}{c}\text { redukcja zawartości } \\
\text { ZEA } \\
\text { reduction of ZEA } \\
\text { content } \\
{[\%]}\end{array}$ & $\begin{array}{c}\text { zawartość ZEA } \\
\text { w próbach po inkubacji } \\
\text { the content of ZEA } \\
\text { in samples after } \\
\text { incubation } \\
{\left[\mu \mathrm{g} / \mathrm{cm}^{3}\right]}\end{array}$ & $\begin{array}{c}\text { redukcja zawartości } \\
\text { ZEA } \\
\text { reduction of ZEA } \\
\text { content } \\
{[\%]}\end{array}$ \\
\hline \multicolumn{6}{|c|}{ Pożywka peptonowa - Pepton medium } \\
\hline 0 & $3,59 \pm 0,15$ a & $2,47 \pm 0,21 \mathrm{~b}$ & 31,10 & $3,00 \pm 0,10 \mathrm{~b}$ & 16,44 \\
\hline 24 & $2,97 \pm 0,08 \mathrm{a}$ & $1,99 \pm 0,45 \mathrm{~b}$ & 33,00 & $2,75 \pm 0,04 \mathrm{~b}$ & 7,50 \\
\hline 48 & $3,02 \pm 0,04 \mathrm{a}$ & $1,96 \pm 0,55 \mathrm{~b}$ & 35,10 & $2,81 \pm 0,03 \mathrm{~b}$ & 7,00 \\
\hline 72 & $2,99 \pm 0,20 \mathrm{a}$ & $2,04 \pm 0,20 \mathrm{~b}$ & 31,77 & $2,71 \pm 0,38 \mathrm{ab}$ & 9,40 \\
\hline \multicolumn{6}{|c|}{ Bufor PBS - PBS buffer } \\
\hline 0 & $5,01 \pm 0,10 \mathrm{a}$ & $4,08 \pm 0,18 \mathrm{~b}$ & 18,56 & $4,19 \pm 0,20 \mathrm{~b}$ & 16,37 \\
\hline 24 & $4,84 \pm 0,21 \mathrm{a}$ & $2,49 \pm 0,30 \mathrm{c}$ & 48,55 & $2,36 \pm 0,26 \mathrm{c}$ & 51,24 \\
\hline 48 & $4,88 \pm 0,16 \mathrm{a}$ & $2,67 \pm 0,35 \mathrm{~d}$ & 45,29 & $2,27 \pm 0,40 \mathrm{c}$ & 53,48 \\
\hline 72 & $4,84 \pm 0,09$ a & $2,73 \pm 0,25 \mathrm{~cd}$ & 43,60 & $1,73 \pm 0,24 \mathrm{~cd}$ & 64,26 \\
\hline
\end{tabular}

Wartości średnie oznaczone tą samą literą nie różnią się istotnie $(\mathrm{p}<0.05)$

The average values with the same letter are not significantly different $(\mathrm{p}<0,05)$

ZEA - zearalenon - zearalenone 
W pożywce peptonowej, szczep $R$. erythropolis, powodował zmniejszenie ilości ZEA o 31,10-35,10\% w stosunku do prób kontrolnych. Zasadniczą redukcję odnotowano już w pierwszych minutach po wprowadzeniu toksyny do pożywki zawierającej bakterie, po kolejnych 24 h ilość toksyny obniżyła się nieznacznie, po czym utrzymywała się na stosunkowo stałym poziomie. Podobnie w przypadku szczepu $R$. fascians obserwowano redukcję zawartości ZEA na poziomie $16,44 \%$ tylko $\mathrm{w}$ pierwszych minutach procesu a w kolejnych dniach efektywność procesu usuwania toksyny była znacznie niższa. Należy podkreślić, że procentową redukcję zawartości ZEA odniesiono do ilości toksyny w próbkach kontrolnych w poszczególnych dniach, w których widać wahania stężenia ZEA, chociaż zmiany te były statystycznie nieistotne. Może to być związane ze środowiskiem, w jakim prowadzono reakcję. Zastosowana pożywka zawierała różnorodne składniki, jak: pepton, hydrolizat kazeiny czy ekstrakt drożdżowy, które mogły wiązać się $\mathrm{z}$ toksyną $\mathrm{w}$ trakcie inkubacji. Biorąc pod uwagę zmiany ilościowe toksyny $\mathrm{w}$ trakcie $72 \mathrm{~h}$ inkubacji, a nie tylko procentową redukcję $\mathrm{w}$ stosunku do próbek kontrolnych (tab. 1) widać, że w ciągu pierwszych 24 godzin, bakterie dość szybko obniżały ilość ZEA, natomiast w kolejnych dniach ilość toksyny utrzymywała się na stosunkowo stałym poziomie. Znacznie większą efektywnością charakteryzował się R. erythropolis PCM 2150.

W buforze stwierdzono wyższą efektywność procesu usuwania zearalenonu $\mathrm{W}$ porównaniu $\mathrm{z}$ pożywką peptonową (tab. 1). Dotyczyło to obydwu badanych szczepów. W przypadku szczepu $R$. fascians ilość ZEA zmniejszyła się z 16,37-64,26\%, w zależności od czasu inkubacji. Z kolei $R$. erythropolis redukował ilość ZEA od 18,56$43,60 \%$. W tym środowisku największy spadek zawartości toksyny odnotowano po 24 godzinach inkubacji. W kolejnych dniach stężenie ZEA albo utrzymywało się na stosunkowo stałym poziomie, jak w próbach zawierających bakterie $R$. erythropolis, bądź sukcesywnie obniżało się, jak stwierdzono to w przypadku bakterii $R$. fascians. Przez pierwsze 24 godziny efektywność obu szczepów w usuwaniu toksyny była porównywalna. W ciągu kolejnych 48 godzin, zawartość ZEA w próbkach zawierających bakterie
$R$. erythropolis pozostała na stałym poziomie, podczas gdy $R$. fascians powodował dalszą redukcję zawartości toksyny.

Według danych literaturowych, niektóre mikroorganizmy mogą przeprowadzać degradację mikotoksyn, bądź przekształcać je w inne formy. Szczególne zainteresowanie naukowców budzi możliwość degradowania aflatoksyn, stąd najwięcej danych literaturowych dotyczy tego właśnie związku. Taką zdolność stwierdzono m.in. u bakterii Nocardia corynebacteroides (Ciegler i wsp. 1966), Mycobacterium fluoranthenivorans (Hormisch i wsp. 2004), czy Rhodococcus erythropolis (Shih i Marth 1975). Opisuje się również degradację lub transformację innych toksyn, w tym fuzaryjnych, m.in. toksyny $\mathrm{T}-2$, zearalenonu czy deoksyniwalenolu, przez różne mikroorganizmy (Molnar i wsp. 2004; Schatzmayr i wsp. 2006). Należy jednak podkreślić, że informacje dotyczące bakterii rodzaju Rhodococcus w tej tematyce są bardzo ograniczone. Z badań Cserháti i wsp. (2013) wynika, że szczepy należące do różnych gatunków w obrębie rodzaju Rhodococcus degradują m.in.: aflatoksynę B1, ochratoksynę A, toksynę T-2, a także zearalenon. W przypadku tej ostatniej toksyny efektywność procesu zależała w dużym stopniu od szczepu bakterii.

\section{Wnioski / Conclusions}

1. Badane szczepy bakterii z rodzaju Rhodococcus wykazywały zdolność do redukcji stężenia zearalenonu w badaniach modelowych.

2. Porównując skuteczność badanych szczepów w usuwaniu zearalenonu stwierdzono, że była ona zależna od środowiska, w jakim prowadzono proces.

3. Biorąc pod uwagę brak produktów metabolizmu ZEA w badanych próbkach można przypuszczać, że mechanizmem odpowiedzialnym za redukcję zawartości ZEA była adsorpcja toksyny do powierzchni komórek.

4. Efektywność procesu redukcji zawartości mikotoksyny przez bakterie Rhodococcus sp. była wyższa w buforze niż w pożywce peptonowej. Największe obniżenie ilości zearalenonu odnotowano po 24 godzinach inkubacji.

\section{Literatura / References}

Alberts J.F., Engelbrecht Y., Steyn P.S., Holzapfel W.H., van Zyl W.H. 2006. Biological degradation of aflatoxin $\mathrm{B}_{1}$ by Rhodococcus erythropolis cultures. International Journal of Food Microbiology 109: 121-126.

Bennett J.W., Klich M. 2003. Mycotoxins. Clinical Microbiology Reviews 16: 497-516.

Chełkowski J. 2009. Mikotoksyny, grzyby toksynotwórcze i mikotoksykozy. http://www.cropnet.pl/dbases/mycotoxins.pdf [dostęp: 12.02.2015].

Chiba H., Agematu H., Kaneto R., Terasawa T., Saka K., Dobaski K., Yoshioka T. 1999. Rhodopeptins, novel cyclic tetrapeptide with antifungal activity from Rhodococcus spp. Journal of Antibiotics 52: 695- 699.

Ciegler A., Lillehoj E.B., Peterson R.E., Hall H.H. 1966. Microbial detoxification of aflatoxin. Applied Microbiology 14 (6): $934-939$.

Cserháti M., Kriszt B., Krifaton C., Szoboszlay S., Háhn J., Tóth Sz., Nagy I., Kukolya J. 2013. Mycotoxin-degradation profile of Rhodococcus strains. International Journal of Food Microbiology 166 (1): 176-185.

Dua M., Singh A., Sethunathan N., Johri A.K. 2002. Biotechnology and bioremediation, successes and limitations. Applied Microbiology and Biotechnology 59: 143-152.

Emrich K., Wilde F., Miedaner T., Piepho H. 2008. Approach for adjusting the Fusarium head blight rating to a phenological date in inoculated selection experiments of wheat. Theoretical and Applied Genetics 117: 65-73.

Hormisch D., Hormisch D., Brost I., Kohring G.W., Giffhorn F., Kroppenstedt R.M., Stackebradt E., Färber P., Holzapfel W.H. 2004. Mycobacterium fluoranthenivorans sp. nov., a fluoranthene and Aflatoxin B1 degrading bacterium from contaminated soil of a former coal gas plant. Systematic and Applied Microbiology 27 (6): 653-660. 
Kapturowska A.U., Zielińska K.J., Stecka K., Kupryś M.P. 2010. Ocena skażenia pasz ochra-toksyną A i metody ich dekontaminacji. Journal of Research and Applications in Agricultural Engineering 55 (3): 156-157.

Łobocka M. 2002. Liniowe plazmidy bakteryjne. Kosmos - Problemy Nauk Biologicznych 256: 284-285.

Masai E., Sugiyama K., Iwashita N., Shimizu S., Hauschild J.E., Hatta T., Kimbara K., Yano K., Fukuda M. 1997. The bphDEF metacleavage pathway genes involved in biphenyl/polychlorinated biphenyl degradation are located on a linear plasmid and separated from the initial bphACB genes in Rhodococcus sp. strain RHA1. Gene 187: 141-149.

Molnar O., Schatzmayr G., Fuchs E., Prillinger H. 2004. Trichosporon mycotoxinivorans sp. nov., a new yeast species useful in biological detoxification of various mycotoxins. Systematic and Applied Microbiology 27 (6): 661-671.

Pokrzywa P., Cieślik E., Topolska K. 2007. Ocena zawartości mikotoksyn w wybranych produktach spożywczych. Żywność Nauka Technologia Jakość 3 (52): 139-146.

Schatzmayr G., Zehner F., Täubel M., Schatzmayr D., Klimitsch A., Loibner A.P., Binder E.M. 2006. Microbiologicals for deactivating mycotoxins. Molecular Nutrition \& Food Research 50 (6): 543-551.

Shih C.N., Marth E.H. 1975. Aflatoxin can be degraded by the mycelium of Aspergillus parasiticus. Zeitschrift für LebensmittelUntersuchung und Forschung 158 (6): 361-362.

Suchorzyńska M., Misiewicz A. 2009. Mikotoksynotwórcze grzyby fitopatogeniczne z rodzaju Fusarium i ich wykrywanie technikami PCR. Postępy Mikrobiologii 48 (3): 221-225.

Twarużek M., Grajewski J., Błajet-Kosicka A. 2012. Skażenia grzybami i występowanie toksyn Fusarium w ziarnie kukurydzy w latach 2009-2011 w Polsce. [Fungal contamination and occurrence of Fusarium toxins in maize in the years 2009-2011 in Poland]. Progress in Plant Protection/Postępy w Ochronie Roślin 52 (4): 1065-1069. 